\title{
Infection hazard of exposure to intestinal parasites, $H$. pylori and hepatitis viruses among municipal sewage workers: a neglected high risk population
}

\author{
Original \\ Article \\ Faika I Hassanein ${ }^{1}$, Inas M Masoud ${ }^{2}$, Amany I Shehata ${ }^{3}$
}

Departments of Microbiology and Immunology ${ }^{1}$, Analytical and Pharmaceutical Chemistry $^{2}$, Faculty of Pharmacy and Drug Manufacturing, Pharos University in Alexandria, and Tropical Health, High Institute of Public Health ${ }^{3}$, Alexandria University, Alexandria, Egypt

\begin{abstract}
Background: Waste water may contain pathogenic human and animal excreta-derived micro-organisms that can cause infections. Municipal sewage workers are a relevant neglected high-risk population especially in the absence of effective protective equipment and lack of hygienic practices mainly washing hands.

Objective: The present study aims to assess the hazards of infection with micro-organisms among municipal sewage workers as a neglected population, besides those infections that maybe acquired via sources other than their occupational hazard.

Subjects and Methods: A cross-sectional study was conducted on sewage workers from different sectors in Alexandria Governorate, Egypt. Collected stool samples were subjected to the following techniques; Kato-Katz, ether concentration, Jones' Media culture, modified Ziehl-Neelsen, and quick hot Gram-chromotrope staining. Stool samples were also tested for Helicobacter pylori antigen (H. pylori Ag). Serum was separated for detection of viral hepatitis $\mathrm{C}$ antibodies (HCV Ab), and HBV surface antigen (HBVs Ag).

Results: Out of the 410 examined workers, 289 (70.5\%) were infected; among them 111 (38.4\%) had mixed infections. It was found that 56.8\%, and 31.2\% harbored intestinal parasitic infections (IPIs) and $H$. pylori, respectively; and $12.2 \%$ had hepatitis mainly HCV (9.8\%). Protozoal infections amounted to 54.6\%, and only 5.9\% had helminthic infections. Blastocystis spp. was the most prevalent parasite (46.8\%) followed by Cryptosporidium spp., Entamoeba histolytica/dispar and Microsporidium spp. (15.6\%, 11.7\%, and 7.8\%, respectively). Almost equal percentages were recorded for single IPI and multiple infections (28.3\%and 28,5\% respectively). Significantly higher rates of IPIs and $H$. pylori were observed among workers who were in frequent contact with sewage. Also, IPIs were statistically higher among young workers ( $<40$ years), while hepatitis was significantly more prevalent among those from rural areas.

Conclusion: Although almost all the detected microbiological infectious hazards can affect sewage workers via sources other than their occupational hazard, our findings call for the importance of self-protection measures that should be in association with regular medical investigation and treatment.
\end{abstract}

Keywords: Egypt, H. pylori, intestinal parasites, neglected population, sewage workers, viral hepatitis.

Received: 15 June, 2019, Accepted: 16 July, 2019.

Corresponding Author: Faika I Hassanein, Tel. : 0020 1280388035, E-mail: Faika.ibrahim@pua.edu.eg

Print ISSN: 1687-7942, Online ISSN: 2090-2646, Vol. 12, No. 2, Ausgust, 2019.

\section{INTRODUCTION}

Water-borne diseases are associated with lack of safe sanitation practices ${ }^{[1]}$. Waste water treatment plant (WWTP) workers are obliged to work in harsh and dirty conditions as it is difficult to maintain good hygienic practices and very difficult to avoid accidental contact with sewage ${ }^{[2]}$. Hazards include chemicals that enter sewage treatment plants as industrial effluents, as well as pathogenic microorganisms found in sewage sludge. Waste water treatment (WWT) results in the generation of aerosols containing chemicals, microorganisms, and solvent vapors ${ }^{[3]}$. Related symptoms have been reported among sewage workers, including eye and nose irritation, lower airway and skin symptoms, headache, fatigue, and dizziness ${ }^{[4]}$. An increase in the risk of asthma as well as decrease in lung function values, chronic bronchitis, toxic pneumonitis, cardiovascular degeneration, and musculoskeletal disorders have been also reported ${ }^{[5,6]}$.

Sewage pathogenic microorganisms are derived from human and animal feces. The presence of protozoal cysts and helminthic eggs in waste water and sludge 
is well documented ${ }^{[7,8]}$. These cysts and eggs are highly resistant to destruction in humid environments and can last for a long time up to years as in the case of Ascaris eggs $^{[9]}$. Most protozoal cysts are directly infective while helminthic eggs, with exception of E. vermicularis and $H$. nana, are only infective after a period of maturation in the environment. Their embryonic development requires oxygen thus growth is limited in sludge due to the lack of aeration ${ }^{[10]}$. However, the time and conditions in which helminthic eggs are present in certain WWT facilities can allow this embryonic development as indicated by the detection of infective stages of $A$. lumbricoides and T. trichiura eggs in sludge samples ${ }^{[9]}$. Contact with sewage is therefore associated with a risk of IPIs, resulting in augmentation of gastrointestinal symptoms ${ }^{[11]}$.

Viral hepatitis is a growing concern of public health especially in developing countries. Both hepatitis viruses $\mathrm{B}$ and $\mathrm{C}$ are associated with chronic infections in addition to considerable morbidity and mortality. Both have been implicated as leading causes of hepatocellular carcinoma in up to $78 \%$ of the hepatitisinfected cases around the world ${ }^{[12]}$. HBV is stable on environmental surfaces for at least seven days, while HCV can be detected in liquid environment for up to five months ${ }^{[13]}$. Thus, exposure of sanitary workers to occupational injuries may expose their wounds to viral hepatitis. Those in low-waged employments in which occupational safety is compromised are more liable to infection than in high-waged professions ${ }^{[12]}$. In contrast, hepatitis A virus (HAV) causes a self-limited acute inflammatory liver disease ${ }^{[14]}$. The virus is shed in high concentrations in the stool of acutely infected individuals and it can survive in moist environments for weeks to months. Data regarding the risk of association of HAV and sewage exposure were conflicting, with the majority denying such an association ${ }^{[15-17]}$. Hepatitis E virus (HEV) is the most common cause of acute viral hepatitis, with a wide range of clinical manifestations, but asymptomatic infections are the most common ${ }^{[18]}$. Drinking contaminated water is the main mode of transmission especially in developing countries ${ }^{[19]}$. The virus can be detected in raw sewage and secondary effluent but it was not present in the tertiary effluent samples. Several studies concluded that sewage was not a source of infection with HEV for sewage workers ${ }^{[19-21]}$.

On the other hand, Friis et al. described the increased risks for various cancers among sewage workers; one of them was stomach cancer ${ }^{[22]}$. H. pylori is suspected because it has been associated with several types of gastric diseases, for example: chronic gastritis, atrophic gastritis and peptic ulcers ${ }^{[23]}$, thus favoring its association with an increased risk for cancer of the stomach. Recently the International Agency for Research on Cancer ${ }^{[24]}$ classified it as a human class I carcinogen. Thus, exposure risks for $H$. pylori among sewage workers may possibly predispose them to cancer stomach.
Municipal waste water workers are considered as a high risk population and they are a neglected subpopulation as there is minimal data available regarding their health status in the last decade in Egypt. Therefore, the present work aims to assess the prevalence of different microbial hazards among this group in Alexandria Governorate.

\section{SUBJECTS AND METHODS}

A cross-sectional study was conducted between April and September 2016. The study was carried out in WWTPs draining four main sector sites of Alexandria Governorate, Egypt.

Study sites: 1) Middle sector with an area of $68 \mathrm{~km}^{2}$ and a population size of 545,833 . About the third of its land constitutes farming lands and slums. 2) Western sector with an area of $20.7 \mathrm{~km}^{2}$ and a population size of 532,097, has no farming lands but has many slums areas. 3) El- Montazah sector with an area of $92 \mathrm{~km}^{2}$ and a population size of 1,190,287; the largest part of its area constitutes farming land with some slums. 4). Eastern sector with an area of $35 \mathrm{~km}^{2}$ and a population size of 985,786; farming lands constitute a large part of its area (most of Abis rural areas) in addition to some slums.

Study design: All day-shift workers were asked to participate in the study. Those who agreed to give a blood sample and two stool specimens (collected on alternate days) were included in the study (410 workers). An interviewing questionnaire including socio-demographic and disease history data, was fulfilled for every worker. Collected stool and blood samples were transported to the Parasitological Laboratory of the High Institute of Public Health, Alexandria University for processing.

Stool samples: Fresh stool samples were subjected to Kato-Katz technique for detecting intestinal helminthes ${ }^{[25]}$ and Jones' media culture for blastocystosis ${ }^{[26]}$. A thin film was prepared for staining using the quick hot Gram-chromotrope method for microsporidiosis ${ }^{[27]}$. Fresh stool samples were also tested by chromatographic rapid technique for detecting $H$. pylori antigen (Ag) using the Ecotest ${ }^{\circledR} H$. pylori antigen kit (Assure Tech Co., Hangzhou, China) according to the manufacturer's instructions ${ }^{[28]}$. Formalin (10\%) preserved stool samples were processed using the formalin-ether concentration technique ${ }^{[29]}$. The sediment was examined for intestinal parasites, and then a thin film was prepared for staining by Modified Ziehl-Neelsen for intestinal coccidia ${ }^{[25]}$.

Blood samples: As HBV and HCV were the main two viruses responsible for fulminant and chronic hepatitis and due to limitation in funding resources, the sewage workers were screened only for these two viruses. 
Separated sera were tested for HCV antibodies and HBVs Ag using an enzyme-linked immunosorbent assay (ELISA) [ACON Laboratories, Inc., San Diego, USA] according to manufacturer's instructions ${ }^{[30,31]}$. All cases above the cut-off value $(0.168$ for HCV antibodies and 0.1344 for HBVs Ag) were considered positive.

Statistical analysis: Data were entered, verified, and analyzed using SPSS version 20.0 (IBM, Armonk, USA). Pearson' chi-squared or Fisher's exact tests were used and were considered statistically significant at $P<0.05$.

Ethical considerations: An ethical approval was obtained from the ethical committee of the High Institute of Public Health. A written permission was also obtained from the Chairman of Directors of the Sewerage Company in Alexandria. A signed, written consent was written by every participant after the aim of the research was explained and after strict confidentiality was ensured. All participants were personally informed about their stool and blood test results. Parasitic infections were treated, while HCV $\mathrm{Ab}$ and HBs Ag positive workers were referred to $\mathrm{a}$ specialist.

\section{RESULTS}

The age of workers examined ranged from 20 to 60 years with a mean age of $46.87 \pm 8.325$. Most of them were urban dwellers (58.5\%). The duration of their work in the WWTPs ranged from 2 to 44 years with $68.5 \%$ of them having worked subterranean for $>20$ years. The majority (75.4\%) were frequently in contact with sewage during their work, without the use of any protective tools. Among the WWTP the Western sector (site 2) included the highest number of workers (222; 54.1\%). Gastroenteritis was the most frequent complain $(34.4 \%)$, followed by eye, skin, and chest allergies (Table 1).

Table (2) showed that out of 410 examined workers, $289(70.5 \%)$ were infected with pathogens. Mixed infections were diagnosed in 111 workers (27.1\%). IPIs, H. pylori infection and viral hepatitis were detected as single infection in $31.5 \%, 8.5 \%$ and $3.9 \%$, respectively.

The protozoal infection rate was higher than the helminth infection rate $(54.6 \%$ vs $5.9 \%)$. Blastocystis spp. was the most prevalent protozoa (46.8\%) followed by Cryptosporidium spp. (15.6\%), E. histolytica/dispar (11.7\%), Microsporidium spp. (7.8\%), and G. lamblia (5.4\%). Lower rates were detected for $C$. cayetanensis, D. fragilis, and $I$. belli $(1.7 \%, 1.2 \%$, and $0.2 \%$, respectively). With regards to helminth infections, $S$. mansoni showed the highest rate of infection $(3.7 \%)$ followed by $A$. lumbricoides, and $H$. nana (1\% each), then E. vermicularis $(0.2 \%)$ (Table 3). Furthermore, 43 workers $(10.5 \%)$ had $E$. coli cysts while only $6(1.5 \%)$ showed I. butchlli cysts.
Table 1. Characteristics and complaints of municipal sewage workers, Alexandria, Egypt.

\begin{tabular}{|c|c|c|c|}
\hline \multicolumn{2}{|l|}{ Characteristics } & \multirow{2}{*}{$\begin{array}{c}\text { Total No. } \\
=\mathbf{4 1 0} \\
149 \\
261\end{array}$} & \multirow{2}{*}{$\begin{array}{c}\begin{array}{c}\text { Frequency } \\
\text { (\%) }\end{array} \\
36.3 \\
63.7\end{array}$} \\
\hline Age & $\begin{array}{l}20->40 \\
40-60\end{array}$ & & \\
\hline $\begin{array}{l}\text { Area of } \\
\text { residence }\end{array}$ & $\begin{array}{l}\text { Urban } \\
\text { Rural }\end{array}$ & $\begin{array}{l}240 \\
170\end{array}$ & $\begin{array}{l}58.5 \\
41.5\end{array}$ \\
\hline $\begin{array}{l}\text { Contact with } \\
\text { sewage* }\end{array}$ & $\begin{array}{l}\text { Rare } \\
\text { Frequent }\end{array}$ & $\begin{array}{l}101 \\
309\end{array}$ & $\begin{array}{l}24.6 \\
75.4\end{array}$ \\
\hline $\begin{array}{l}\text { Duration of } \\
\text { the work }\end{array}$ & $\begin{array}{l}<20 \\
\geq 20\end{array}$ & $\begin{array}{l}129 \\
281\end{array}$ & $\begin{array}{l}31.5 \\
68.5\end{array}$ \\
\hline Work location & $\begin{array}{l}\text { Site } 1 \\
\text { Site } 2 \\
\text { Site } 3 \\
\text { Site } 4\end{array}$ & $\begin{array}{c}77 \\
222 \\
79 \\
32\end{array}$ & $\begin{array}{c}18.8 \\
54.1 \\
19.3 \\
7.8\end{array}$ \\
\hline Compliant & $\begin{array}{l}\text { Gastroenteritis } \\
\text { Eye allergy } \\
\text { Skin allergy } \\
\text { Chest allergy } \\
\text { Arthritis } \\
\text { Others** }\end{array}$ & $\begin{array}{l}141 \\
79 \\
56 \\
52 \\
30 \\
22\end{array}$ & $\begin{array}{c}34.4 \\
19.3 \\
13.7 \\
12.7 \\
7.3 \\
5.4\end{array}$ \\
\hline & tal & 239 & 58.3 \\
\hline
\end{tabular}

Table 2. Rates of microbial infections among sewage workers.

\begin{tabular}{|c|c|c|c|}
\hline \multicolumn{2}{|c|}{ Microbial infections } & \multirow{2}{*}{$\begin{array}{c}\text { Positive } \\
127 \\
35 \\
16\end{array}$} & \multirow{2}{*}{$\begin{array}{c}\text { \% } \\
31.0 \\
8.5 \\
3.9\end{array}$} \\
\hline $\begin{array}{l}\text { Single } \\
\text { infection }\end{array}$ & $\begin{array}{l}\text { IPIs } \\
\text { H. pylori } \\
\text { Viral hepatitis }\end{array}$ & & \\
\hline \multirow[t]{2}{*}{$\begin{array}{l}\text { Mixed } \\
\text { infection }\end{array}$} & $\begin{array}{l}\text { IPIs and } H . \text { pylori } \\
\text { IPIs and hepatitis } \\
H . \text { pylori and hepatitis } \\
\text { IPIs, H. pylori and hepatits }\end{array}$ & $\begin{array}{c}77 \\
18 \\
5 \\
11\end{array}$ & $\begin{array}{l}18.8 \\
4.4 \\
1.2 \\
2.7\end{array}$ \\
\hline & Total & 111 & 27.1 \\
\hline & Total & 289 & 70.5 \\
\hline
\end{tabular}

N.B.: Total IPIs 233 (56.8\%), total H.pylori 128 (31.2\%), total viral hepatitis 50 (12.2\%):HCV (9.8\%) and HBV (2.9\%).

Table 3. Infection rates of different parasites among sewage workers

\begin{tabular}{|c|c|c|c|}
\hline \multicolumn{2}{|c|}{ Parasitic infections } & \multirow{2}{*}{$\begin{array}{c}\text { Positive } \\
192\end{array}$} & \multirow{2}{*}{$\frac{\%}{46.8}$} \\
\hline \multirow{9}{*}{ Protozoa } & Blastocystis spp. & & \\
\hline & Cryptosporidium spp. & 64 & 15.6 \\
\hline & E. histolytica/dispar & 48 & 11.7 \\
\hline & Microsporidium spp. & 32 & 7.8 \\
\hline & G. lamblia & 22 & 5.4 \\
\hline & C. cayetanensis & 7 & 1.7 \\
\hline & D. fragilis & 5 & 1.2 \\
\hline & I. belli & 1 & 0.2 \\
\hline & Total & 224 & 54.6 \\
\hline \multirow{5}{*}{ Helminthes } & S. mansoni & 15 & 3.7 \\
\hline & A. lumbricoides & 4 & 1.0 \\
\hline & H. nana & 4 & 1.0 \\
\hline & E. vermicularis & 1 & 0.2 \\
\hline & Total & 24 & 5.9 \\
\hline
\end{tabular}


Total IPIs detection rates were significantly higher among workers $<40$ years old and among those frequently exposed to sewage water during their work (63.8\% and $62.8 \%$, respectively) than among those aged 40-60 years and those rarely exposed to sewage water $(52.9 \%$ and $38.6 \%$, respectively) $(P=0.032$ and $P>0.001$, respectively). Moreover, a significantly higher IPIs detection rate was observed among workers in sites 2,3 , and 4 than those in site $1(63.1 \%, 63.3 \%$, and $65.6 \%$ vs $28.6 \%, P<0.001)$. Although the IPIs detection rate was higher among workers with a history of $>20$ years of work and among those residing in rural areas, the differences were statistically insignificant. For $H$. pylori infection, a significantly higher rate was detected among sewer-men who came into frequent contact with sewage water than among those with infrequent contact $(34 \%$ vs $22.9 \%, P=0.035)$. Viral hepatitis infection rates were significantly higher among workers residing in rural areas (16.5\%) than among those from urban areas $(9.2 \%)(P=0.026)$. Concerning total infection, significant higher rates were observed among workers in frequent contact with waste water and among those aged $<40$ years old compared to workers rarely contacting sewage and those aged $>40$ years old $(77 \%$ and $77.9 \%$ vs $50.5 \%$ and $66.3 \%$, with $P$ values $<0.001$ and $=0.013$, respectively). Moreover, a statistically significant difference $(P<0.001)$ was detected between infection rates of workers from different sites with the highest rate (77.2\%) in site 3 ) and the lowest rate $(46.8 \%)$ in site 1 (Table 4 ).

Table (5) shows that $28.3 \%$ of examined sewage workers presented with single IPI and an almost equal total percentage $(28.6 \%)$ were suffering from two or more IPIs. Double infections amounted to $18.8 \%$ while three or more infections percentage recorded $9.8 \%$.

Table 4. Percentage of different microbial infections among sewage workers in relation to socio-demographic factors.

\begin{tabular}{|c|c|c|c|c|c|c|c|c|c|c|}
\hline \multirow{2}{*}{\multicolumn{2}{|c|}{ Variable }} & \multirow{3}{*}{$\begin{array}{l}\text { No. } \\
149 \\
261\end{array}$} & \multicolumn{2}{|c|}{ IPIs } & \multicolumn{2}{|c|}{ H. pylori } & \multicolumn{2}{|c|}{ Viral hepatitis } & \multicolumn{2}{|c|}{ Total infections } \\
\hline & & & \multirow{2}{*}{$\begin{array}{c}\text { No. (\%) } \\
95(63.8) \\
138(52.9)\end{array}$} & \multirow{2}{*}{$\frac{P \text { value }}{0.032^{*}}$} & \multirow{2}{*}{$\begin{array}{c}\text { No. (\%) } \\
49(32.9) \\
79(30.3)\end{array}$} & \multirow{2}{*}{$\frac{P \text { value }}{0.582}$} & \multirow{2}{*}{$\begin{array}{c}\text { No. (\%) } \\
23(15.4) \\
27(10.3)\end{array}$} & \multirow{2}{*}{$\frac{P \text { value }}{0.130}$} & \multirow{2}{*}{$\begin{array}{c}\text { No. (\%) } \\
116(77.9) \\
173(66.3)\end{array}$} & \multirow{2}{*}{$\frac{P \text { value }}{0.013^{*}}$} \\
\hline Age & $\begin{array}{l}20->40 \\
40-60\end{array}$ & & & & & & & & & \\
\hline $\begin{array}{l}\text { Sewage } \\
\text { contact }\end{array}$ & $\begin{array}{l}\text { Rare } \\
\text { Frequent }\end{array}$ & $\begin{array}{l}101 \\
309\end{array}$ & $\begin{array}{c}39(38.6) \\
194(62.8)\end{array}$ & $<0.001 *$ & $\begin{array}{c}23(22.9) \\
105(34.0)\end{array}$ & $0.035^{*}$ & $\begin{array}{c}10(9.9) \\
40(12.9)\end{array}$ & 0.417 & $\begin{array}{c}51(50.5) \\
238(77.0)\end{array}$ & $<0.001 *$ \\
\hline $\begin{array}{l}\text { Work } \\
\text { duration }\end{array}$ & $\begin{array}{l}<20 \\
\geq 20\end{array}$ & $\begin{array}{l}129 \\
281\end{array}$ & $\begin{array}{c}70(54.3) \\
163(58.0)\end{array}$ & 0.477 & $\begin{array}{l}34(26.4) \\
94(33.5)\end{array}$ & 0.150 & $\begin{array}{c}12(9.3) \\
38(13.5)\end{array}$ & 0.225 & $\begin{array}{c}86(66.7) \\
203(72.2)\end{array}$ & 0.250 \\
\hline Residence & $\begin{array}{l}\text { Urban } \\
\text { Rural }\end{array}$ & $\begin{array}{l}240 \\
170\end{array}$ & $\begin{array}{l}132(55.0) \\
101(59.4)\end{array}$ & 0.374 & $\begin{array}{l}76(31.7) \\
52(30.6)\end{array}$ & 0.816 & $\begin{array}{c}22(9.2) \\
28(16.5)\end{array}$ & $0.026^{*}$ & $\begin{array}{l}167(69.6) \\
122(71.8)\end{array}$ & 0.633 \\
\hline Site & $\begin{array}{l}\text { Site } 1 \\
\text { Site } 2 \\
\text { Site } 3 \\
\text { Site } 4\end{array}$ & $\begin{array}{c}77 \\
222 \\
79 \\
32\end{array}$ & $\begin{array}{c}22(28.6) \\
140(63.1) \\
50(63.3) \\
21(65.6)\end{array}$ & $<0.001 *$ & $\begin{array}{l}15(19.5) \\
73(32.9) \\
30(38.0) \\
10(31.3)\end{array}$ & 0.075 & $\begin{array}{c}28(11.3) \\
25(16.2) \\
9(11.4) \\
2(6.3)\end{array}$ & 0.277 & $\begin{array}{c}36(46.8) \\
170(76.6) \\
61(77.2) \\
22(68.8)\end{array}$ & $<0.001 *$ \\
\hline \multicolumn{2}{|c|}{ Total } & 410 & \multicolumn{2}{|c|}{$233(56.8)$} & \multicolumn{2}{|c|}{$128(31.2)$} & \multicolumn{2}{|c|}{$50(12.2)^{* *}$} & \multicolumn{2}{|c|}{$289(70.5)$} \\
\hline
\end{tabular}

Percentages were compared using Chi square test or Fisher Exact test

*Statistically significant at $P \leq 0.05$

** Out of the 50 cases of viral hepatitis, 40 (9.8\%) were HCV and 12 (2.9\%) were HBV, i.e. 2 (0.5\%) were co-infected.

Table 5. Multiplicity of IPIs in relation to the different socio-demographic factors of sewage workers

\begin{tabular}{|c|c|c|c|c|c|c|c|c|}
\hline \multirow{2}{*}{\multicolumn{2}{|c|}{ Variable }} & \multirow{3}{*}{$\begin{array}{l}\text { No. } \\
149 \\
261\end{array}$} & \multicolumn{2}{|c|}{ Single } & \multicolumn{2}{|c|}{ Double } & \multicolumn{2}{|c|}{ Triple or more } \\
\hline & & & \multirow{2}{*}{$\begin{array}{c}\text { No. (\%) } \\
50(33.6) \\
66(25.3)\end{array}$} & \multirow{2}{*}{$\begin{array}{c}\boldsymbol{P} \text { value } \\
0.074\end{array}$} & \multirow{2}{*}{$\begin{array}{l}\text { No. (\%) } \\
29(19.5) \\
48(18.4)\end{array}$} & \multirow{2}{*}{$\begin{array}{c}\boldsymbol{P} \text { value } \\
0.789\end{array}$} & \multirow{2}{*}{$\begin{array}{c}\text { No. (\%) } \\
16(10.7) \\
24(9.2)\end{array}$} & \multirow{2}{*}{$\frac{\boldsymbol{P} \text { value }}{0.613}$} \\
\hline Age & $\begin{array}{l}20->40 \\
40-60\end{array}$ & & & & & & & \\
\hline $\begin{array}{l}\text { Sewage } \\
\text { contact }\end{array}$ & $\begin{array}{l}\text { Rare } \\
\text { Frequent }\end{array}$ & $\begin{array}{l}101 \\
309\end{array}$ & $\begin{array}{l}19(18.8) \\
97(31.8)\end{array}$ & $0.015^{*}$ & $\begin{array}{l}14(13.9) \\
63(20.4)\end{array}$ & 0.145 & $\begin{array}{c}6(5.9) \\
34(11.0)\end{array}$ & 0.137 \\
\hline $\begin{array}{l}\text { Work } \\
\text { duration }\end{array}$ & $\begin{array}{l}<20 \\
\geq 20\end{array}$ & $\begin{array}{l}129 \\
281\end{array}$ & $\begin{array}{l}34(26.4) \\
82(29.2)\end{array}$ & 0.555 & $\begin{array}{l}24(18.6) \\
53(18.9)\end{array}$ & 0.951 & $\begin{array}{c}12(9.3) \\
28(10.0)\end{array}$ & 0.834 \\
\hline Residence & $\begin{array}{l}\text { Urban } \\
\text { Rural }\end{array}$ & $\begin{array}{l}240 \\
170\end{array}$ & $\begin{array}{l}69(28.8) \\
47(27.6)\end{array}$ & 0.807 & $\begin{array}{l}40(16.7) \\
37(21.8)\end{array}$ & 0.193 & $\begin{array}{c}24(10.0) \\
16(9.4)\end{array}$ & 0.843 \\
\hline Site & $\begin{array}{l}\text { Site } 1 \\
\text { Site } 2 \\
\text { Site } 3 \\
\text { Site } 4\end{array}$ & $\begin{array}{c}77 \\
222 \\
79 \\
32 \\
\end{array}$ & $\begin{array}{l}16(20.8) \\
66(29.7) \\
24(30.4) \\
10(31.3)\end{array}$ & 0.444 & $\begin{array}{c}5(6.5) \\
47(21.2) \\
19(24.1) \\
6(18.8)\end{array}$ & $0.020^{*}$ & $\begin{array}{c}1(1.3) \\
28(12.6) \\
6(7.6) \\
5(15.6)\end{array}$ & $0.019 *$ \\
\hline \multicolumn{2}{|c|}{ Total } & 410 & \multicolumn{2}{|c|}{$116(28.3)$} & \multicolumn{2}{|c|}{77 (18.8) } & \multicolumn{2}{|c|}{$40(9.8)$} \\
\hline
\end{tabular}

Percentages were compared using Chi square test or Fisher Exact test

*Statistically significant at $P \leq 0.05$ 
The studied sample of workers who had frequent contact with waste water presented with significantly higher single infection when compared to those who had rare contact with the water $(31.8 \%$ vs $18.8 \%$, $P=0.015)$. Workers with a work history of $\geq 20$-year showed higher infection rates with single (29.2\%) and double $(18.9 \%)$ infections compared to those who worked for $<20$ years but without statistical significance. Concerning the area of residence, those living in both urban and rural areas presented with a high rates of single and double infections $(28.8 \%$ and $27.6 \%$ respectively), but the differences were not statistically significant. Double infections (24.1\%) and triple or more infections $(15.6 \%)$ were significantly higher among workers in site 3 and site 4 respectively than among workers in other sites $(P=0.020$ and 0.019 , respectively). The WWTPs from these two sites drain waste water from areas which are mostly rural (Table 5).

\section{DISCUSSION}

Working as sewer-men involves several occupational hazards that expose them to harmful conditions. In the present study, $58.3 \%$ of workers were suffering from several complaints, mainly gastroenteritis (34.4\%) followed by eye, skin, and chest allergies, in addition to arthritis. These appeared to be common complaints, as they were similarly reported by other studies worldwide ${ }^{[4,5,10,32]}$. A study conducted in Menoufiya Governorate, Egypt, reported a more significant prevalence of abdominal pain, body aches, respiratory symptoms (asthma and dyspnea), and left ventricular hypertrophy among sewage workers than in non-exposed workers $(49 \%, 30 \%, 19 \%$, and $30 \%$, respectively, vs $21 \%, 7 \%, 5 \%$, and $9 \%$ respectively in controls) ${ }^{[33]}$. About half (47\%) of sewage workers from Cairo suffered significantly higher rates of abdominal pain and body aches $(29.4 \%)$, as compared to the controls $(20 \% \text { and } 2.9 \% \text {, respectively })^{[34]}$. Another Egyptian study conducted in Mansoura sewage treatment plant revealed that $43.3 \%$ of workers suffered from heartburn, which was the only significant gastrointestinal symptom detected when compared to controls ${ }^{[35]}$. Saad et al. ${ }^{[36]}$ reported that respiratory symptoms (either acute or chronic), headache, fatigue, eye and skin irritations were highly prevalent among sewage workers as compared to the control group ${ }^{[36]}$. Viruses such as Norwalk agent, other microorganisms, or even endotoxins have been suggested as possible causes for most of these observed symptoms ${ }^{[3]}$. The possible exposure of workers to gases such as hydrogen disulfide, methane, ammonia, and carbon monoxide could be another explanation for such symptoms since hydrogen sulfide, even at low concentrations, has irritating effects on eyes and respiratory tract $\mathrm{t}^{[37]}$. In our study, the workers claimed that arthritic pains, including lower back and knees pains, may be related to their work in confined pipes spaces.
Sewage workers are subjected to other biological hazards due to dirty hands while eating, drinking, smoking, and waste water splashing on their faces. Therefore, there is subsequently a higher risk of IPIs although the infective doses of these parasites may be minimal ${ }^{[34]}$. In our study 233 out of 410 sewage workers (56.8\%) were infected with IPIs. It is worth mentioning that frequency of contact with sewage water and young age of workers was significantly associated with IPIs; the latter group being more active during their work rendering them at higher risk of exposure. Our results were higher than those reported in other studies from Egypt, in which the recorded rates of IPIs ranged from $30 \%$ to $43.5 \%$, among other neglected populations such as immunocompromised ${ }^{[38]}$ and mentally handicapped patients ${ }^{[39]}$. Related to our study on a neglected population, a rate of $21.7 \%$ was detected among street sweepers and waste collection workers from BeniSuef. The main parasites detected were E. histolytica, G. lamblia, and H. nana ${ }^{[40]}$. Another study conducted in Alexandria revealed that about half of the solid-waste handlers were infected with Cryptosporidium spp. (23.4\%) followed by Microsporidium spp. and S. mansoni $(20.25 \% \text { and } 13.3 \% \text {, respectively })^{[41]}$. Hammouda et al. ${ }^{[42]}$ reported that sewage workers from Alexandria were at a higher risk of developing IPIs especially ascariasis and amoebiasis than the control group. Nail detritus examination from the workers proved they were at high risk for E. vermicularis infections ${ }^{[42]}$. Surveys conducted in different countries worldwide also emphasized the occupational risk of IPIs among workers exposed to sewage ${ }^{[43-48]}$. A study conducted in Rennes, France reported significant difference in $E$. histolytica detection rate among municipal sewer-men versus non-sewage workers $\left(11 \%\right.$ versus $2 \%{ }^{[43]}$. The mean prevalence of IPIs among sewage employees from Paris, France was $11.8 \%$, with predominance of G. lamblia and T. trichiura ${ }^{[44]}$. In New Zealand, Mitchell et al., ${ }^{[45]}$ identified sewage exposure as a significant risk factor mainly for Giardiasis. Similarly, an increased risk of hookworm infections ${ }^{[46]}$ and Giardiasis $^{[47]}$ were reported among waste water farmers in Pakistan compared to farming households using non-waste water irrigation water. Also, in a study performed in Kampala to evaluate IPIs prevalence in adult population groups with different exposures to waste water. Sewermen, whether those collecting fecal sludge from houses or those maintaining channel drainage, presented with lower IPIs detection rates than those in our study (36\% and $42 \%$, respectively ${ }^{[48]}$.

However, there is much controversy regarding association of IPIs and municipal working. Clark et $a l .{ }^{[49]}$ revealed that IPIs were not frequent among sewage workers when compared to control group over a 12-month period study conducted in USA (5.4\% vs $14.5 \%$ ). Results of a Kampala study revealed that sewer-men presented with lower detection rates than farmers who used untreated waste water to grow their crops $(76 \%)^{[48]}$. Also, a study conducted by 
Fuhrimann et al. ${ }^{[50]}$ in different communities exposed to waste water in urban and peri-urban transition zones in Hanoi, Vietnam, showed that waste water exposure was not directly associated with IPIs. The investigators explained their conclusion by the high level of awareness of the population to the different health risks ${ }^{[50]}$.

Our results revealed predominance of protozoa infections (54.6\%, vs 5.9\% for helminthic infections). The highly detected protozoa was Blastocystis spp. (46.8\%), followed by Cryptosporidium spp., E. histolytica/dispar, Microsporidium spp. and G. lamblia in descending order of frequency (15.6\%-5.4\%). A high protozoa burden was observed among sewer-men from Mansoura, and rates of $65 \%$ and $20 \%$ were detected for E. histolytica and G. lamblia, respectively ${ }^{[35]}$. A positive correlation between protozoa infection among sewage workers and the duration of exposure to sewage was also reported in an earlier German study. Their results revealed that $E$. histolytica antibody rate was significantly higher among the sewage workers compared to the control ${ }^{[51]}$. The study conducted in Kampala also confirmed our results. Rates of $27 \%$ and $30 \%$ were recorded for protozoa infections among workers dealing with fecal sludge and those maintaining sewage channels, respectively, while infection with helminths was $12 \%$ and $17 \%$, respectively ${ }^{[48]}$.

In our study, only $5.9 \%$ of workers harbored helminth worms. Schistosomiasis, the only pathogen that may not be acquired due to exposure to sewage, was the most prevalent helminth infection in the present study (3.7\%). Thirteen out of the fifteen cases of schistosomiasis (87\%) were residing in rural areas where most probably they got infected. In addition, the other low records of helminth infections with $A$. lumbricoides, $H$. nana, and $E$. vermicularis suggested that helminth infections are not related to sewage exposure (i.e. not an occupation hazard). The low rate of helminth infection was also recorded in Egypt, but for other neglected populations. A rate of $1.5 \%$ was reported among mentally handicapped individuals with E. vermicularis being the only helminth found ${ }^{[39]}$. The study conducted in Sohag Governorate revealed that only $4 \%$ of the examined school children were infected with helminth parasites with predominance of $H$. nana. This could be a result of increase in the general awareness about personal hygiene and ways of parasites transmission or could be a result of anthelminth campaign carried out in Egypt ${ }^{[52]}$.

A debate about the association of $H$. pylori prevalence and working in WWTPs was evident from results of different studies worldwide in spite of the higher prevalence of stomach cancer recorded among these workers (the relative risk was about 2 to 2.5$)^{[22]}$, and in spite of the higher risk for gastric carcinoma (up to six fold) among $H$. pylori-infected individuals compared to uninfected persons ${ }^{[53]}$. Our results revealed a total $H$. pylori rate of $31.2 \%$. This rate was found to be significantly higher among sewermen who were in frequent contact with sewage than among those with infrequent contact $34 \%$ versus $22.9 \%$, respectively). Our result agreed with two other Egyptian studies. The investigators detected $H$. pylori IgG seropositivity in $47 \%$ of sewage workers in Cairo compared to the controls (23\%). Seropositivity rates increased in workers' aged $>40$ years and with the increase in the duration of work ( $>20$ years of work). However, no statistical significance was observed ${ }^{[34]}$. In Mansoura sewage treatment plant, the prevalence of $H$. pylori among workers (56.7\%) was statistically higher than in unexposed individuals $(16.7 \%)$. The risk of infection was significantly higher among workers with poor personal protective equipment, those who worked under these conditions for $>20$ years, workers older than 45 years, and poorly educated workers ${ }^{[35]}$. In 2004 , the higher percentage of $H$. pylori IgG seropositivity was also reported in Zurich among workers exposed to waste water compared to non-exposed workers $(50 \%$ vs 34\%)[54]. Similarly, Flemish municipal sewage workers presented with a higher rate of $H$. pylori IgG antibodies compared to controls (16.7\% vs $13.6 \%)$. In addition, no significant association was found between the $H$. pylori infection and gastrointestinal symptoms, duration of occupational exposures, or with hygienic practices $^{[55]}$. It is worth mentioning that the previously mentioned rates detected in the present study $34 \%$ and $22.9 \%$ ) are higher or similar to other detection rates reported in other neglected populations; school children and mentally challenged patients in rehabilitation centers in Alexandria $(24 \%$ and $27.1 \%$, respectively $)^{[56,57]}$.

In contrast, Swedish sewer-men did not reveal any increase in the risk of $H$. pylori-associated seropositivity when compared to control ${ }^{[58]}$. The prospective cohort study carried out in Zurich (Switzerland) in 2009 revealed that H. pylori IgG and IgA seroconversion (incidence rates) were very close in control and waste water exposed subjects. Although $H$. pylori was reported in waste water, the investigators attributed their results to its coccoid form in water that is not able to colonize human stomach ${ }^{[59]}$.

Hepatitis B and C continue to be long-term major health problems on the African continent, especially in Egypt. Workers exposed to occupational injuries could expose themselves to greater risks for viral hepatitis, especially if occupational safety is compromised[60]. The present study revealed that $12.2 \%$ of sewer-men showed seropositive results either to HCV Ab (9.8\%) or HBs Ag (2.9\%) or both $(0.5 \%)$. Our detected rates are within the range of rates reported by several studies from Egypt and are similar to the general population prevalence. HBV Ag prevalence in Egypt was reported to be of intermediate endemicity (2\%$8 \%$ ), and about 2 to 3 million Egyptians were chronic HBV carriers $^{[61]}$. In 2015, the Egyptian Health Issue 
Survey estimated that HCV antibody among individuals aged 15-59 years was $10 \%$, which was about a $30 \%$ decline from what was reported $(14.7 \%)$ in 2008 by the Egyptian Demographic Health Survey. This significant reduction in HCV prevalence was explained by the aging of the group of individuals infected during the mass schistosomiasis treatment campaign due to syringe reuse (1960-1980) (older than 59 years) and by application of the prevention control measures concerning injection safety and awareness ${ }^{[60]}$. Similarly, no differences were found in the prevalence of antibodies against HBV between sewage workers from Denmark and either Danish landscape gardeners or office workers ${ }^{[62]}$. Furthermore, the American Conference of Governmental Industrial Hygienists in 2001 reported that no cases of HBV were linked with sewage exposure, most likely due to substantial dilution of the virus in the waste water ${ }^{[63]}$.

In contrast, a higher rate of HBV Ag (38.2\%) among sewer-men compared to control group $(17.2 \%)$ was reported in a study carried out in Cairo. Higher rates were also recorded among workers younger than 40 years and among those working for more than 20 years. However, both results were not significant ${ }^{[34]}$. The study conducted in Alexandria in 2015, reported a high HBV seroprevalence (36.1\%), but lower HCV seroprevalence $(8.4 \%)$ among municipal solid waste workers $^{[64]}$. Worldwide, only three studies reported an increase in exposure risk to HBV and HCV among sewage workers $^{[2,12,65]}$. Two studies were carried out in Greece, the first reported a high prevalence of HBV markers (43.9\%) among employees of a sewage company, and only $6.6 \%$ of them were HBV Ag carriers ${ }^{[65]}$. Similarly, the second study reported a significantly higher antiHBs antigen percentage among waste water workers compared to controls (32.4\% versus 5.8\%; $\mathrm{P}<0.0001)$. The investigators observed that increasing age and sewage contact were significantly associated with HBV infections ${ }^{[2]}$. Later, high rates for HCV Ab and HBV Ag (36.4\% and $33.6 \%$, respectively) were recorded by Sheikh et al., ${ }^{[12]}$ among sewage workers in Pakistan.

In conclusion, high rates reported in the present study (289 out of $410 ; 70.5 \%$ ) emphasizes the susceptibility of an important neglected population of sewage workers to infections, especially IPIs. Thus, health education concerning transmission modes and the importance of the self-protection measures should be included with regular medical investigation and treatment. The possible spreading of $H$. pylori through waste water requires further investigation, especially in areas with a high infection prevalence.

Author contribution: Authors equally shared data and sample collections, laboratory work, data analysis, manuscript writing and research funding.

Conflict of interest: Authors confirm that there are no known conflicts of interest associated with this study.

\section{REFERENCES}

1. Strunz EC, Addiss DG, Stocks ME, Ogden S, Utzinger J, Freeman MC. Water sanitation hygiene, and soil-transmitted helminth infection: a systematic review and meta-analysis. PLoS Med 2014; 11(3): e1001620.

2. Arvanitidou M, Mamassi P, Vayona A. Epidemiological evidence for vaccinating waste water treatment plant workers against hepatitis $\mathrm{A}$ and hepatitis B virus. Eur J Epidemiol 2004; 19(3): 259-262.

3. Melbostadt E, Eduard W, Skogstad A, Sandven P, Lassen J, Søstrand P, et al. Exposure to bacterial aerosols and work-related symptoms in sewage workers. Am J Ind Med 1994; 25: 59-63.

4. Rylander R. Health effects among workers in sewage treatment plants. J Occup Env Med 1999; 56(5): 354-357.

5. Friis L, Norbäck D, Edling C. Self-reported asthma and respiratory symptoms in sewage workers. J Occup Health 1999; 41: 87-90.

6. Thorn J, Beijer L, Rylander R. Work related symptoms among sewage workers: a nationwide survey in Sweden. Occup Environ Med 2002; 59(8): 562-566.

7. Gassmann L, Schwartzbrod J. Waste water and Giardia cysts. Wat Sci Tech 1991; 24: 183-186.

8. Schwartzbrod J, Mathieu C, Thevenot MT, Baradel JM, Schwartzbrod L. Parasitic and virologic analysis of sewage sludge. TSM-L'eau 1986; 81: 149-153.

9. Gaspard P, Wiart J, Schwartzbrod J. A method for assessing the viability of nematode eggs in sludge. Environ Tech 1996; 17(4): 415-420.

10. Wharton DA. Ascaris spp.: Water loss during desiccation of embryonating eggs. Exp Parasitol 1979; 48(3): 398-406.

11. Friis L, Agréus L, Edling C. Abdominal symptoms among sewage workers. Occup Med (Lond) 1998; 48:251-253.

12. Sheikh SH, Aziz S, William GP, Ansari F, Waqqar S, Bano S. Hepatitis prevalence of epidemic magnitude among sanitary workers in Pakistan. IOSR-JDMS 2014; 13(6): 58-61.

13. Ciesek S, Friesland M, Steinmann J, Becker B, Wedemeyer H, Manns MP, et al. How stable is the hepatitis $\mathrm{C}$ virus (HCV)? Environmental stability of HCV and its susceptibility to chemical biocides. J Infect Dis 2010; 201(12):1859-1866.

14. Brugha R, Heptonstall J, Farrington P, Andren S, Perry K. Risk of hepatitis A infection in sewage workers. Occup Environ Med 1998; 55: 567-569.

15. Heng BH, Goh KT, Doraisingham S, Quek GH. Prevalence of hepatitis A virus infection among sewage workers in Singapore. Epidemiol Infect 1994; 113: 121-128.

16. Nuebling M, Hofmann F. Task profile and risk of occupational hepatitis A infection in sewerage workers. Int Arch Occup Environ Health 2001; 4: 589-593. 
17. Venczel L, Brown S, Frumkin H, Simmonds-Diaz J, Deitchman S, Bell BP. Prevalence of hepatitis A virus infection among sewage workers in Georgia. Am J Ind Med 2003; 43: 172-178.

18. Van der Poel WHM. Food and environmental routes of hepatitis E virus transmission. Curr Opin Virol 2014; 4: 91-96.

19. Girones R, Carratalà A, Calgua B, Calvo M, RodriguezManzano J, Emerson S. Chlorine inactivation of hepatitis E virus and human adenovirus 2 in water. J Water Health 2014; 12: 436-442.

20. Yazaki Y, Mizuo H, Takahashi M, Nishizawa T, Sasaki $\mathrm{N}$, Gotanda Y, et al. Sporadic acute or fulminant hepatitis E in Hokkaido, Japan, may be food-borne, as suggested by the presence of hepatitis E virus in pig liver as food. J Gen Virol 2003; 84: 2351-2357.

21. Barnaud E, Roge'e S, Garry P, Rose N, Pavio N. Thermal inactivation of infectious hepatitis $\mathrm{E}$ virus in experimentally contaminated food. Appl Environ Microbiol 2012; 78: 5153-5159.

22. Friis L, Edling C, Hagmar L. Mortality and incidence of cancer among sewage workers: A retrospective cohort study. Br J Ind Med1993; 50(7): 653-657.

23. Karnes WE Jr, Samloff IM, Siurala M, Kekki M, Sipponen P, Kim SW, et al. Positive serum antibody and negative tissue staining for Helicobacter pylori in subjects with atrophic body gastritis. Gastroenterology1991; 101(1): 167-174.

24. International Agency for Research on Cancer (IARC). Schistosomes, liver flukes, and Helicobacter pylori. IARC monograph on the evaluation of carcinogenic risks to humans. Lyon: IARC 1994; 61: 270 pages.

25. Markell EK, John DT, Krotoski WA (Eds). Markell and Voge's Medical Parasitology. W. B. Saunders Company, Philadelphia 2006.

26. Jones WR. The experimental infection of rats with Entamoeba histolytica; with a method for evaluating the anti-amebic properties of new compounds. Ann Trop Med Parasitol 1946; 40: 130-140.

27. Garcia LS. Laboratory Identification of the Microsporidia. J Clin Microbiol. 2002; 40(6): 18921901.

28. Gisbert JP, Pajares JM. Diagnosis of Helicobacter pylori infection by stool antigen determination: a systematic review. Am J Gastroenterol 2001; 96:2829-2838.

29. Becker SL, Lohourignon LK, Speich B, Rinaldi L, Knopp S, N'goran EK et al. Comparison of the Flotac-400 dual technique and the formalin-ether concentration technique for diagnosis of human intestinal protozoon infection. J Clin Microbiol. 2011; 49(6): 2183-90.

30. Blumberg BS. The discovery of Australian antigen and its relation to viral hepatitis. Vitro 1971; 7:223.

31. Choo Ql, Kuo G, Weiner AJ, Overby LR, Bradley DW, Houghton $M$. Isolation of a cDNA clone derived from a blood borne non-A, non-B viral hepatitis genome. Science 1989; 244:359.
32. Friedrich M, Cermak T, Heiller I. Spinal troubles in sewage workers: epidemiological data and work disability due to low back pain. Int Arch Occup Environ Health 2000; 73(4): 245-254.

33. Al-Batanony MA, El-Shafie MK. Work-related health effect among waste water treatment plants workers. Int J Occup Environ Med 2011; 2(4):237-244.

34. Helal SF, Rashed LA. Some biological health hazards among sewer workers. EJOM 2009; 33(2): 119-130.

35. Foad MF, Awadalla NJ. Prevalence and risk factors of Helicobacter pylori and intestinal protozoal infections among sewage workers in Mansoura, Egypt. EJOM 2011; 35(1): 67-81.

36. Saad A, Ebrahim Y, Abdel-Shakour A. Respiratory health problems of sewage workers. EJOM 2003; 27(2): 201-228.

37. Richardson DB. Respiratory effects of chronic hydrogen sulfide exposure. Am J Ind Med 1995; 28 : 99-108.

38. Baiomy AMS, Mohamed KAA, Ghannam MAM, Shahat SA, Al-Saadawy AS. Opportunistic parasitic infections among immune compromised Egyptian patients. J Egypt Soc Parasitol 2010; 40(3): 797807.

39. Shehata AI, Hassanein F. Intestinal parasitic infections among mentally handicapped individuals in Alexandria, Egypt. Ann Parasitol 2015; 61(4):275-281.

40. Ewis AA, Rahma MA, Mohamed ES, Hifnawy TM, Arafa AE. Occupational morbidities among street sweeper and waste collectors at Beni-Suef, Egypt. EJOM 2013; 37(1):79-94.

41. Eassa SM, El-Wahab EW, Lotfi SE, El Masry SA, Shatat HZ, Kotkat AM. Risk factors associated with parasitic infection among municipality solid-waste workers in an Egyptian community. J Parasitol 2016; 102(2): 214-221.

42. Hammouda NA, El-Gebali WM, Razek MK. Intestinal parasitic infection among sewage workers in Alexandria, Egypt. J Egypt Soc Parasitol 1992; 22(2): 299-303.

43. Doby JM, Duval JM, Guiguen C, Deunff J. Résultats d'examens coprologiques systématiques effectués chez les égoutiers de la ville de Rennes. Fréquence de l'amibiase liée à l'exercice de cette profession. Medecine et Maladies Infectieuses 1979; 9(12):707-711.

44. Schlosser O, Grall D, Laurenceau MN. Intestinal parasite carriage in workers exposed to sewage. Eur J Epidemiol 1999; 15(3): 261-265.

45. Mitchell P, Graham P, Brieseman MA. Giardiasis in Canterbury: The first nine months reported cases. NZ Med J 1993; 106: 350-352.

46. Ensink JH, van der Hoek W, Mukhtar M, Tahir Z, Amerasinghe FP. High risk of hookworm infection among waste water farmers in Pakistan. Trans $\mathrm{R}$ Soc Trop Med Hyg 2005; 99(11): 809-818.

47. Ensink JH, van der Hoek W, Amerasinghe FP. Giardia duodenalis infection and waste water irrigation 
in Pakistan. Trans R Soc Trop Med Hyg 2006; 100(6):538-542.

48. Fuhrimann S, Winkler MS, Kabatereine NB, Tukahebwa EM, Halage AA, Rutebemberwa E, et al. Risk of intestinal parasitic infections in people with different exposures to waste water and fecal sludge in Kampala, Uganda: A cross-sectional study. PLoS Negl Trop Dis 2016; 10(3): 1-19.

49. Clark CS, Linnemann CC Jr, Clark JG, Gartside PS. Enteric parasites in workers occupationally exposed to sewage. J Occup Med 1984; 26(4):273275.

50. Fuhrimann S, Winkler MS, Pham-Duc P, DoTrung D, Schindler C, Utzinger J, et al. Intestinal parasite infections and associated risk factors in communities exposed to waste water in urban and peri-urban transition zones in Hanoi, Vietnam. Parasit Vectors 2016; 9(1): 537.

51. Knobloch J, Bialek R, Hagemann J. Intestinal protozoal infestation in persons with occupational sewage contact. Dtsch Med Wochenschr 1983; 108(2): 57-60.

52. El-Nadi NA, Omran EK, Ahmed NS, Fadel EF. Current status of intestinal parasites among elementary school children in Sohag, Egypt. J Adv Parasitol. 2017;3(2):33-40.

53. EUROGAST study group. An international association between $H$. pylori infection and gastric cancer. Lancet 1993; 341(8857):1359-1363.

54. Jeggli S, Steiner D, Joller H, Tschopp A, Steffen R, Hotz P. Hepatitis E, Helicobacter pylori, and gastrointestinal symptoms in workers exposed to waste water. Occup Environ Med 2004; 61(7):622627.

55. Van Hooste $\mathrm{W}$, Charlier A, Rotsaert P, Bulterys S, Moens G, van Sprundel M, et al. Work-related Helicobacter pylori infection among sewage workers in municipal waste water treatment plants in Belgium. Occup Environ Med 2010; 67(2): 91-97.

56. El-Massry AM, Thabett TM, Kassemt AN, Badr ElDin SA. Helicobacter pylori infection among school children in Alexandria: Possible association with intestinal parasitic infections. Bull High Inst Public Health 2003; 33(1):141-156.

57. Hassanein F, Shehata AI, Abdul-Ghani R. G. lamblia and $H$. pylori infections among mentally challenged individuals in rehabilitation centers in Alexandria, Egypt. J Infect Dev Ctries 2017; 11(7): 577-582.

58. Friis L, Engstrand L, Edling C. Prevalence of Helicobacter pylori among sewage workers. Scand J Work Environ Health 1996;22(5):364-368.

59. Tschopp A1, Joller H, Jeggli S, Widmeier S, Steffen R, Hilfiker S, et al. Hepatitis E, Helicobacter pylori and peptic ulcers in workers exposed to sewage: a prospective cohort study. Occup Environ Med 2009; 66(1):45-50.

60. Kandeel A, Genedy M, El-Refai S, Funk AL, Fontanet A, Talaat M. The prevalence of HCV infection in Egypt 2015: implications for future policy on prevention and treatment. Liver Int 2017; 37(1): 45-53.

61. Emara MH. Occult hepatitis B: the Egyptian situation. Trop Gastroenterol 2012; 33(4): 242250.

62. Skinhoj P, Blain Hollinger F, Hovind-Hougen $\mathrm{K}$, Lous B. Infectious liver diseases in three groups of Copenhagen workers: correlation of hepatitis A infection to sewage exposure. Arch Environ Health 1981; 36(3): 139-143

63. American Conference of Governmental Industrial Hygienists (ACGIH). Threshold limit values for chemical substances and physical agents and biological exposure indices. Cincinnati: USA, 2001.

64. Abd El-Wahab EW, Eassa SM, Lotfi SE, Kotkat AM, Shatat HZ, El Masry SA. Seroprevalence, immunostatus and factors associated with blood borne viral infections among Egyptian municipal solid waste workers. J Virol Antivir Res 2015; 4(4): 1-7.

65. Arvanitidou M, Constantinidis TC, Doutsos J, Mandraveli K, Katsouyannopoulos V. Occupational hepatitis B virus infection in sewage workers. Med Lav.1998; 89(5):437-444. 